\title{
CORRESPONDENCE
}

\section{Cities need plants and animals too}

Your 'Science and the city' special issue (Nature 467, issue 7318; 2010) overlooks the potential of urban areas as habitats for native species other than pigeons, rats and cockroaches.

Scientists and planners have traditionally treated human-dominated landscapes as incompatible with nature conservation. But the cost of city development need not include a complete loss of ecological function.

For instance, Norwegian-style green roofs, built with native plant species, would provide energy and allow reduction or collection of water run-off. Other ecological features, such as nesting cavities, could be incorporated into new buildings. Public spaces could host plants for native pollinators and provide habitat links within cities and with surrounding non-urban areas. Urban boundaries can offer resources to edge species that live in these transition areas, as well as to humans.

Patrick R. Huber, Steven E. Greco University of California, USA,prhuber@ucdavis.edu

\section{Water: act now to restore river health}

Urgent measures must be taken to ensure that it does not take a generation to muster the necessary political willpower to restore the health of rivers globally, as C. J. Vörösmarty and colleagues suggest (Nature 467, 555-561; 2010). The livelihoods of 60 million people in the developing world depend on river fisheries, and millions more rely on them for food.

Lessons can be learned from Vietnam's positive actions, for example. Its Vu Gia-Thu Ban river basin is used for hydropower development, but rivers have dam-free stretches, designated after strategic environmental assessment with stakeholder participation (see go.nature.com/ xnbbgr). Developing alternatives to large-scale mainstream dams - including river-bypass systems and micro-hydroelectric power installations for local use - will help to reduce tradeoffs between water security and river biodiversity.

The pessimistic prediction of Vörösmarty et al. may well turn out to be correct for large river systems in Asia, Africa and Latin America, where weak governance of water allocation, dam construction and river management frequently overlooks the dependence of riparian communities on ecosystem health (P. Dugan et al. Ambio 39, 344-348; 2010). Investment is needed now to build adaptive capacity and new livelihood opportunities for poor river communities.

We need much more investment of the kind made by the Consultative Group on International Agricultural Research. This group of publicly funded institutions is developing a programme to benefit poor people who depend on aquatic agricultural systems (see go.nature.com/g98kLv). This will focus initially on the basins of the Mekong, Zambezi and GangesBrahmaputra-Megna rivers. Patrick Dugan, Edward $\mathbf{H}$. Allison The WorldFish Center, Penang, Malaysia, p.dugan@cgiar.org

\section{Water: biofuels sap supplies}

The water footprint of the growing biofuel sector should be factored into discussions about water security (Nature 467, 555-561; 2010).

The rapid expansion of biofuel crops can significantly affect regional hydrological patterns (B. G. Subhadra Science 329, 1282-1283; 2010). In India, for example, jatropha plants - a biofuel feedstock with a large water footprint (W. GerbensLeenes et al. Proc. Natl Acad. Sci. USA 106, 10219-10223; 2009) are increasingly being cultivated in rural areas.

Add to this the rapidly depleting groundwater in northwest India (M. Rodell et al. Nature 460, 999-1002; 2009) and the alarm sounds for prompt policy planning by the government to safeguard India's water resources.

Bobban Subhadra University of

New Mexico, USA,

bsubhadra@salud.unm.edu

\section{Ireland should fund best research}

The Irish government aims to develop our 'smart economy' by prioritizing funding for research that will lead to "innovation" (Nature 467, 895; 2010). This will be achieved through another committee, the fourth in as many years (see go.nature.com/ wepylw).

The composition of this committee suggests that the choice of areas to be funded will probably be driven by commercial demands. That is unlikely to create new jobs, as the government claims.

Ireland should instead concentrate funding on research - any research - that is of consistently high quality (based on non-exchequer funding and prestigious publications) and dump the rest. Such a move would also attract high-quality researchers into the country.

More important than any illdefined concept of innovation, it is crucial that high-calibre but inexperienced researchers get to work on problems with commercial potential, supported by consultants and professionals from industry. Top-class researchers need to be socialized, which is next to impossible in an academic setting.

The cuts to science in Ireland, combined with the government's handling of the remainder, risk turning the clock back 30 years.

Gareth Dyke University College Dublin, Ireland, gareth.dyke@ucd.ie

\section{Concrete helix recalls smallpox win}

The left-handed concrete DNA helix at the Australian National University's John Curtin School of Medical Research (JCSMR) in Canberra is symbolic of one of the world's greatest medical accomplishments (Nature 467, 920; 2010).

A former JCSMR

director, microbiologist Frank Fenner, chaired the World Health Organization Global Commission for the Certification of Smallpox Eradication. Smallpox virus was finally eradicated 30 years ago using a live vaccinia virus vaccine.

Crucial for transcription and for pathogenicity of poxviruses is Z-DNA's left-handed doublehelical structure (A. Rich and S. Zhang Nature Rev. Genet. 4, 566-572; 2003). Vaccinia virus becomes apathogenic if Z-DNA binding is disrupted (T. A.

Brandt and B. L. Jacobs J. Virol. 75, 850-856; 2001).

The Z-form of DNA on the outside of our JCSMR building is an inspiring reminder of the fundamental work done here and that great discoveries can arise from researching unusual and anomalous phenomena. Julio Licinio, Simon Easteal, Ma-Li Wong The Australian National University, Canberra, Australia, julio.licinio@anu.edu.au 